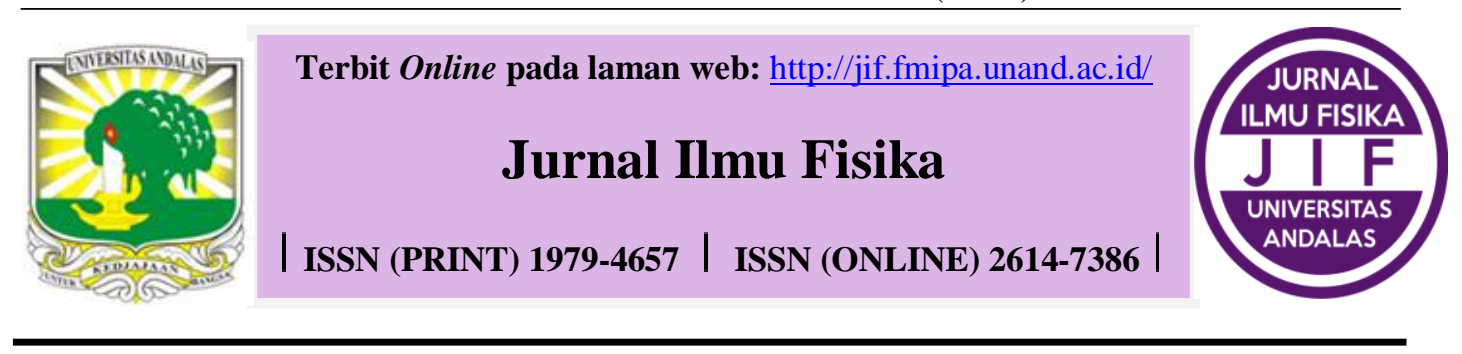

\title{
KAJIAN KETIDAKPASTIAN PENGUKURAN SUHU DAN KELEMBABAN UDARA PADA SENSOR DHT22 BERBASIS ARDUINO UNO
}

\author{
Trias Prima Satya ${ }^{*}$, Fitri Puspasari \\ Departemen Teknik Elektro dan Informatika, Sekolah Vokasi, \\ Universitas Gadjah Mada, Yogyakarta 55281 \\ *Korespondensi ke: trias.primasatya@ugm.ac.id
}

( Diterima:24 Juli 2019; Direvisi: 24 Agustus 2019; Diterbitkan: 01 September 2019)

\begin{abstract}
ABSTRAK
Telah dilakukan penelitian tentang kajian ketidakpastian pengukuran suhu dan kelembaban udara pada sensor DHT22 berbasis Arduino Uno. Tujuan dari penelitian ini adalah merancang termohigrometer dengan menggunakan sensor DHT22 berbasis Arduino Uno dan mengetahui validitas hasil ukur instrumen yang dibuat tersebut. Metode yang digunakan dalam penelitian ini terdiri dari tiga tahap yaitu perancangan perangkat keras, perancangan perangkat lunak, dan pengujian sistem. Pengujian dilakukan dengan menganalisis nilai ketidakpastian dan galat hasil ukurnya pada suhu ruangan. Hasil penelitian ini menunjukkan bahwa termohigrometer yang diuji pada suhu $25^{\circ} \mathrm{C}$ menunjukkan hasil ukur $(24,73 \pm 0,33){ }^{\circ} \mathrm{C}$ dengan galat $1,34 \%$ untuk uji suhu, dan $(48,16 \pm 1,31) \%$ dengan galat $2,72 \%$ untuk uji kelembaban udara. Sedangkan pada suhu ruangan $28^{\circ} \mathrm{C}$ menunjukkan hasil ukur $(28,22 \pm 0,33){ }^{\circ} \mathrm{C}$ dengan galat $1,12 \%$ untuk uji suhu, dan $(42,59 \pm 1,31) \%$ dengan galat $3,07 \%$ untuk uji kelembaban udara. Hasil analisis ketidakpastian menunjukkan bahwa instrumen yang diuji telah sesuai dengan standar pada sheet data sensor DHT22.
\end{abstract}

Kata kunci: Arduino Uno, DHT22, galat, ketidakpastian, sensor

\begin{abstract}
The research of temperature and humidity measurement uncertainty study in the DHT22 sensor based on Arduino Uno has been done. The aims of this research were designing a thermohygrometer using DHT22 sensor based on Arduino Uno and knowing its validity measurement result. The method of this research consists of three stages i.e designing hardware, designing software, and testing system. The testing were done by analysis of uncertainty and error of measurement result in the room temperature. The result of this research show that the thermohygrometer tested under $25^{\circ} \mathrm{C}$ has temperature testing measurement result $(24,73 \pm 0,33)^{\circ} \mathrm{C}$ and error $1,34 \%$, humidity testing measurement result $(48,16 \pm 1,31) \%$ and error $2,72 \%$. The thermohygrometer tested under $28^{\circ} \mathrm{C}$ has temperature testing measurement result $(28,22 \pm 0,33)^{\circ} \mathrm{C}$ and error $1,12 \%$, humidity testing measurement result $(42,59 \pm 1,31) \%$ and error 3,07\%. The uncertainty analysis result of this research show that the instrument was accordance with standard DHT22 sensor data sheet.

Keyword: Arduino Uno, DHT22, error, uncertainty, sensor
\end{abstract}




\section{PENDAHULUAN}

Suhu dan kelembaban udara merupakan salah satu parameter yang penting dalam laboratorium kalibrasi, sehingga perubahannya harus terpantau, terkendali, dan terekam sesuai dengan persyaratannya (Jumaila dan Maulida, 2017). Pengukuran suhu dan kelembaban udara umumnya dilakukan dengan menggunakan termohigrometer. Instrumen termohigrometer ini dapat dirancang dengan baik menggunakan sensor DHT22 berbasis Arduino Uno sebagai mikrokontroler (Saptadi dkk, 2015). Sistem ini banyak dipilih karena beberapa kelebihan diantaranya sifat Arduino yang open source, mudah untuk diprogram, dapat digunakan pada berbagai sistem operasi komputer, dan harganya yang terjangkau (Mihai, 2016). Kalibrasi dilakukan untuk mengetahui kebenaran hasil pengukuran suatu termohigrometer. Salah satu metode kalibrasi tersebut yaitu menggunakan teknik pengukuran kelembaban relatif dari suhu terendah sampai dengan tertinggi pada rentang suhu ruangan. Metode ini banyak dilakukan pada laboratorium di Indonesia dan beberapa NMI (National Metrology Institute) seperti NIS Mesir (Tistomo, 2014). Oleh karena itu, pada penelitian ini akan ditinjau pembuatan termohigrometer menggunakan sensor DHT22 berbasis Arduino Uno. Validasi dilakukan melalui kalibrasi sistem pengukuran kelembaban relatif pada suhu ruangan dengan analisis ketidakpastian, galat, dan koreksi hasil pengukuran.

\section{METODE}

Metode yang digunakan pada penelitian ini terbagi menjadi perancangan perangkat keras, perangkat lunak, serta pengujian alat yang dibuat.

\subsection{Perancangan Perangkat Keras (Hardware)}

Perangkat keras dirancang menggunakan sensor DHT22 untuk mendeteksi suhu dan kelembaban yang terhubung ke Arduino Uno sebagai mikrokontroler. Untuk menampilkan data hasil pengukuran digunakan LCD $4 \times 4$ /Serial Monitor. Blok diagram sistem ditunjukkan pada Gambar 1.

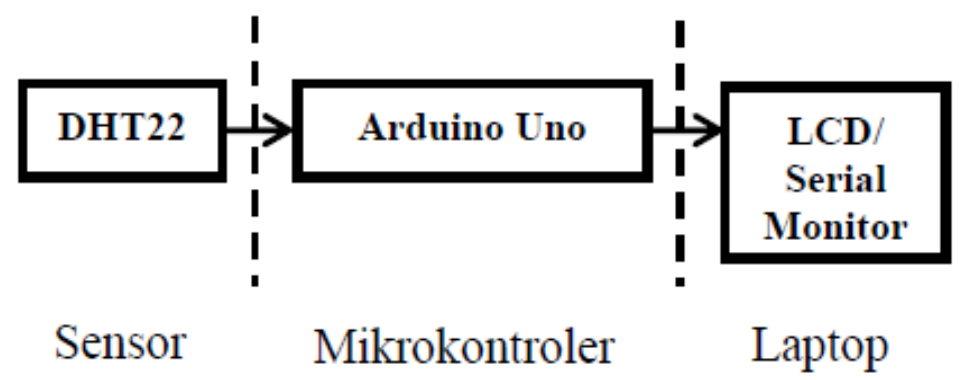

Gambar 1. Blok Diagram sistem.

Penelitian diawali dengan mendesain sistem berupa gambar rangkaian skematik seperti ditunjukkan pada gambar 2. Desain ini bertujuan untuk memastikan bahwa seluruh komponen dapat dirangkai secara sempurna dan sistem dapat bekerja sesuai dengan tujuan penelitian yang ingin dicapai 


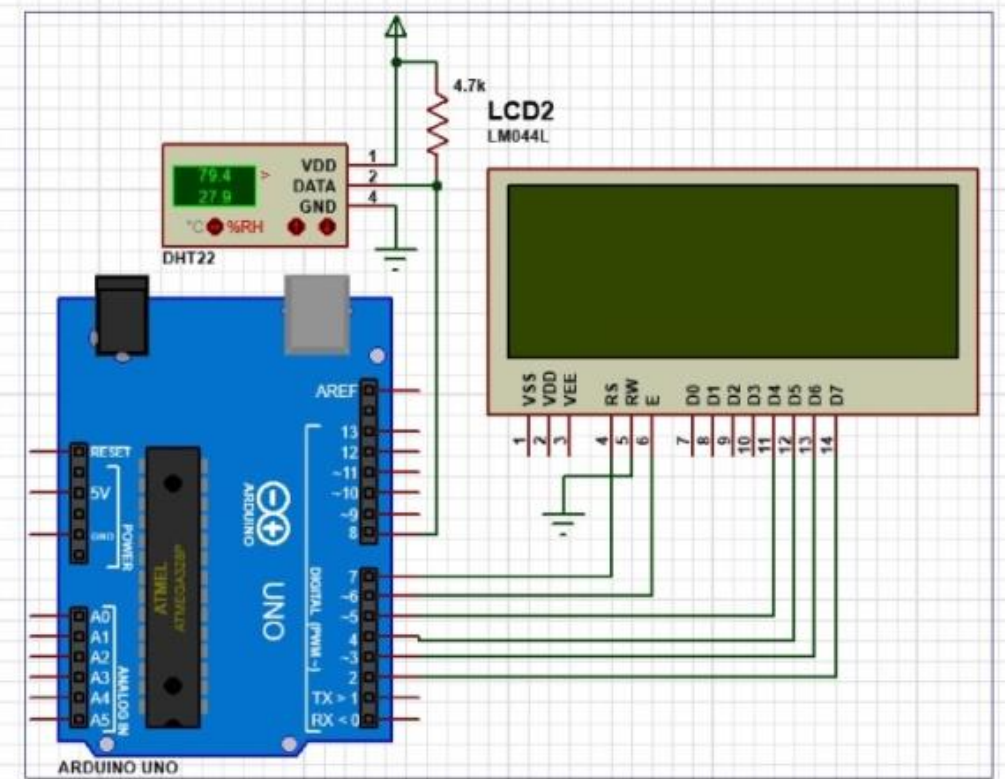

Gambar 2. Rangkaian skematik sistem

Berdasarkan gambar 1 dan gambar 2, selanjutnya sensor DHT22, Arduino Uno dan LCD $4 \times 4$ dirangkai pada papan breadboard sebagai berikut

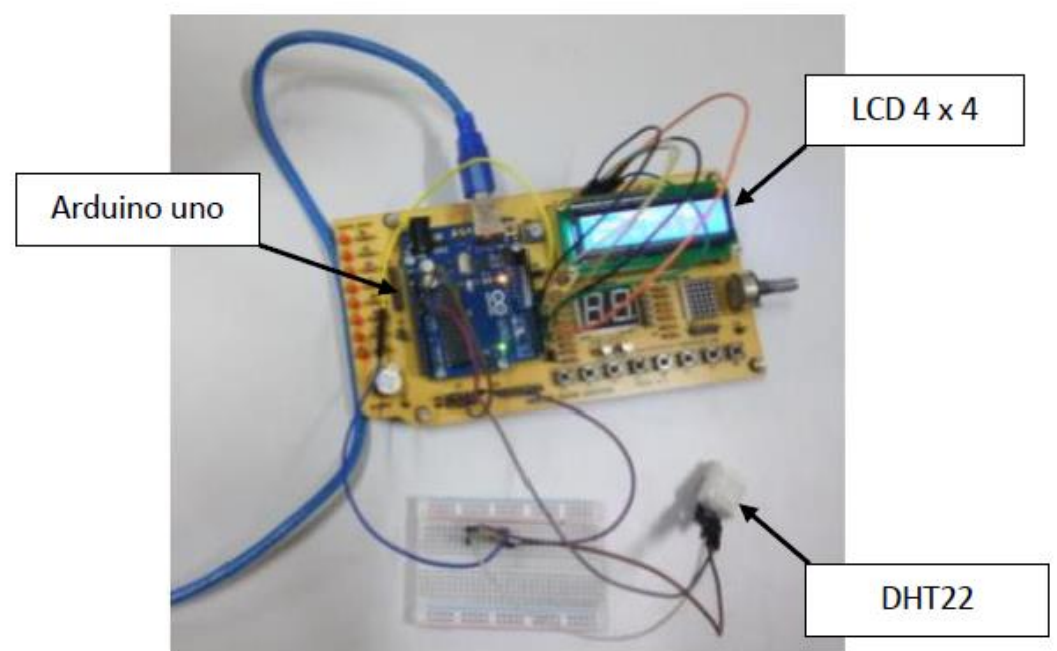

Gambar 3. Rangkaian perangkat keras termohigrometer yang dibuat

\subsection{Perancangan Perangkat Lunak (Software)}

Perangkat lunak dibuat menggunakan instruksi untuk menyalakan sensor DHT22, membaca, serta menampilkan hasil pengukuran pada LCD $4 \times 4$ dan serial monitor. Semua instruksi diatur dalam program software Arduino IDE dengan bahasa pemrograman Arduino. Gambar 4 adalah diagram alir perancangan perangkat lunak pada Arduino Uno. 


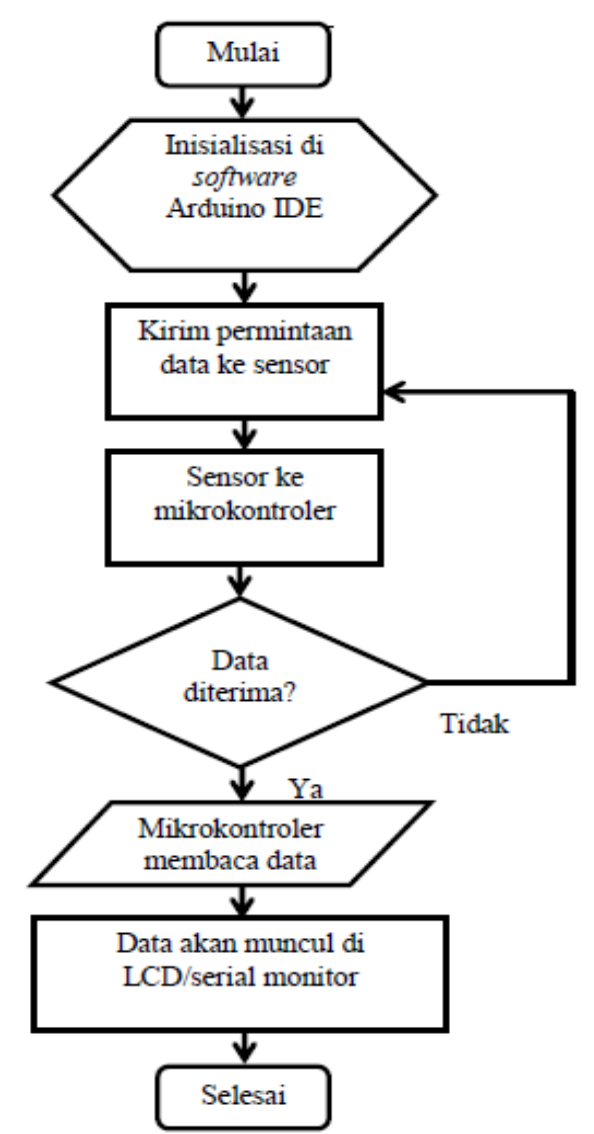

Gambar 4. Diagram alir perancangan perangkat lunak

\subsection{Pengujian Alat yang Dibuat}

Pengujian dilakukan dengan mengoperasikan termohigrometer yang dibuat pada rentang suhu ruangan $25^{\circ} \mathrm{C}$ dan $28^{\circ} \mathrm{C}$. Pengambilan data dilakukan dengan pengulangan $100 \mathrm{kali}$ untuk masing-masing suhu. Sebagai pembanding digunakan termohigrometer standar yang telah terkalibrasi dengan acuan JIS Z 8710-1993 dan ASTM E 77-98. Analisis dilakukan melalui perhitungan nilai rata-rata, nilai koreksi, dan ketidakpastian pengukuran dengan formulasi (KAN, 2002):

Nilai rata-rata didefinisikan sebagai

$$
\bar{x}=\frac{1}{n} \sum x_{i}
$$

dengan $n$ adalah jumlah pengulangan. Sementara nilai koreksi memenuhi relasi

$$
\text { Nilai koreksi }=\text { Nilai benar }(\text { Alat standar })-\text { Hasil Pengukuran. }
$$

Dalam penelitian ini digunakan dua buah tipe ketidakpastian pengukuran. Ketidakpastian Baku Tipe A disimbolkan dengan $U_{A}$

$$
U_{A}=\frac{S_{p}}{\sqrt{n}}
$$


dengan $n$ jumlah data total dan $S_{p}$

$$
S_{p}=\sqrt{\frac{\sum_{i=1}^{m} v_{i} s_{i}}{v_{p}}} ; v_{p}=\sum_{i=1}^{m} v_{i}
$$

merupakan simpangan baku Pooled, $m$ menunjukkan jumlah kelompok pengamatan data, $v_{i}$ adalah derajat kebebasan $m_{i-1}$, dan $s_{i}$ adalah simpangan baku eksperimental dari satu seri $m_{i}$.

Ketidakpastian Baku Tipe B disimbolkan dengan $U_{B}$ yang terdiri dari; sertifikat kalibrasi termohigrometer standar

$$
U_{B 1}=\frac{U_{95} \text { (termohigrometer) }}{k},
$$

ketidakpastian resolusi

$$
U_{B 2}=\frac{0,5 \times \text { resolusi }}{\sqrt{3}},
$$

dan sertifikat kalibrasi clamp meter untuk tegangan listrik yang masuk ke sistem

$$
U_{B 3}=\frac{U_{95}(\text { Clamp Meter })}{k} .
$$

Sehingga dengan demikian, diperoleh ketidakpastian baku gabungan yang dinyatakan sebagai

$$
\begin{aligned}
U_{C} & =\sqrt{\left[\sum_{i=1}^{N} c_{i} U\left(x_{i}\right)\right]^{2}} c_{i} \equiv 1 \\
U_{C} & =\sqrt{\left[\left(1 . U_{B 1}\right)+\left(1 . U_{B 2}\right)+\left(1 . U_{B 3}\right)+\left(1 . U_{A}\right)\right]^{2}}
\end{aligned}
$$

dan ketidakpastian bentangan

$$
U_{95}=U_{C} k \text {, dengan } k=2 .
$$

\section{HASIL DAN DISKUSI}

Dari percobaan pengukuran suhu dan kelembaban udara pada kondisi suhu ruangan $25^{\circ} \mathrm{C}$, menunjukkan bahwa sistem termohigrometer yang dibuat dapat bekerja dengan hasil seperti ditunjukkan pada tabel 1 berikut:

Tabel 1 Hasil pengujian termohigrometer pada suhu ruang $25^{\circ} \mathrm{C}$

\begin{tabular}{lccccccccc}
\hline & $\begin{array}{c}\text { Alat } \\
\text { uji }\end{array}$ & $\begin{array}{c}\text { Alat } \\
\text { Standard }\end{array}$ & Koreksi & $\boldsymbol{U}_{\boldsymbol{A}}$ & $\boldsymbol{U}_{\boldsymbol{B} \boldsymbol{1}}$ & $\boldsymbol{U}_{\boldsymbol{B 2}}$ & $\boldsymbol{U}_{\boldsymbol{B} \boldsymbol{3}}$ & $\boldsymbol{U}_{\boldsymbol{C}}$ & $\boldsymbol{U}_{\mathbf{9 5}}$ \\
\hline Suhu $\left({ }^{\circ} \mathrm{C}\right)$ & 24,73 & 24,21 & $-0,52$ & 0,016 & 0,155 & 0,028 & 0,050 & 0,166 & 0,332 \\
Kelembaban $(\%)$ & 48,16 & 48,56 & 0,40 & 0,044 & 0,650 & 0,028 & 0,050 & 0,654 & 1,308 \\
\hline
\end{tabular}

sedangkan pada percobaan pengukuran suhu dan kelembaban udara pada kondisi suhu ruangan $28^{\circ} \mathrm{C}$ (dilakukan dengan setting variabel yang sama seperti pada pengujian untuk 
suhu ruangan $25^{\circ} \mathrm{C}$ ) diperoleh hasil pengujian sistem termohigrometer seperti ditunjukkan pada tabel 2 berikut:

Tabel 2 Hasil pengujian termohigrometer pada suhu ruang $28^{\circ} \mathrm{C}$

\begin{tabular}{lcclcccccc}
\hline & $\begin{array}{c}\text { Alat } \\
\text { uji }\end{array}$ & $\begin{array}{c}\text { Alat } \\
\text { Standard }\end{array}$ & Koreksi & $\boldsymbol{U}_{\boldsymbol{A}}$ & $\boldsymbol{U}_{\boldsymbol{B} \boldsymbol{1}}$ & $\boldsymbol{U}_{\boldsymbol{B} \mathbf{2}}$ & $\boldsymbol{U}_{\boldsymbol{B} \boldsymbol{3}}$ & $\boldsymbol{U}_{\boldsymbol{c}}$ & $\boldsymbol{U}_{\boldsymbol{9 5}}$ \\
\hline Suhu $\left({ }^{\circ} \mathrm{C}\right)$ & 28,22 & 28,39 & 0,17 & 0,015 & 0,155 & 0,028 & 0,050 & 0,166 & 0,332 \\
Kelembaban $(\%)$ & 42,59 & 42,86 & 0,27 & 0,039 & 0,650 & 0,028 & 0,050 & 0,653 & 1,306 \\
\hline
\end{tabular}

Pengujian termohigrometer pada kondisi suhu ruangan $25^{\circ} \mathrm{C}$ dan $28^{\circ} \mathrm{C}$ dilakukan sebanyak 100 kali pengulangan. Rata-rata hasil pengukuran diperoleh $\bar{T}=24,7^{\circ} \mathrm{C}$ dan $\bar{H}=48,16 \%$ untuk suhu ruangan $25^{\circ} \mathrm{C}$, sedangkan pada suhu ruangan $28^{\circ} \mathrm{C}$ diperoleh $\bar{T}=28,22^{\circ} \mathrm{C}$ dan $\bar{H}=42,59 \%$. Nilai ini kemudian dibandingkan dengan hasil penunjukkan termohigrometer standar untuk menghitung nilai koreksi alat. Nilai koreksi negatif (-) menunjukkan bahwa termohigrometer yang dibuat ketika diaplikasikan untuk pengukuran, maka hasil ukurnya harus dikurangi nilai koreksinya. Sebaliknya nilai koreksi positif (+) menunjukkan bahwa termohigrometer yang dibuat ketika diaplikasikan untuk pengukuran, maka hasil ukurnya harus ditambah nilai koreksinya. Beberapa faktor yang memengaruhi besar kecilnya nilai koreksi alat ukur tersebut diantaranya; berkaitan dengan instrumen standar yang digunakan, kemampuan menjaga dan mempertahankan kondisi lingkungan pengujian yang standar, serta kemungkinan kondisi fisis parameter lainnya yang tidak sesuai dengan standar yang seharusnya (Gupta, 2012).

Ketidakpastian baku tipe-A diestimasi secara statistik. Dari 100 kali pengulangan, data dikelompokkan kedalam 10 seri kelompok data pengamatan $(m=10)$, yang masingmasing kelompok berisi 10 data. Analisis dilakukan dengan menggunakan simpangan baku pooled. Hasil evaluasi ketidakpastian baku tipe A menunjukkan nilai suhu dan kelembaban udara termohigrometer yang dibuat sebesar $U_{A} \bar{T}=0,016^{\circ} \mathrm{C}$ dan $U_{A} \bar{H}=0,044 \%$ untuk suhu ruangan sebesar $25^{\circ} \mathrm{C}$, dan $U_{A} \bar{T}=0,015^{\circ} \mathrm{C}$ dan $U_{A} \bar{H}=0,039$ $\%$ untuk suhu ruangan sebesar $28^{\circ} \mathrm{C}$. Nilai ini menunjukkan bahwa simpangan hasil ukur termohigrometer yang dibuat kecil (>5\%), sehingga nilai presisi hasil ukurnya tinggi. Artinya alat ini dapat digunakan untuk mengukur besaran suhu dan kelembaban udara secara berulang-ulang dengan hasil yang konstan.

Ketidakpastian tipe B diestimasi selain secara statistik yang didasarkan pada justifikasi ilmiah menggunakan semua informasi relevan yang tersedia (KAN, 2002). Beberapa informasi yang dapat digunakan untuk estimasi ketidakpastian baku tipe B pada percobaan ini diperoleh dari sertifikat kalibrasi termohigrometer standar, ketidakpastian resolusi, dan ketidakpastian pengukuran tegangan listrik yang masuk ke dalam sistem. Pada sertifikat kalibrasi termohigrometer standar diketahui nilai ketidakpastian suhu sebesar $0,13^{\circ} \mathrm{C}$ dan ketidakpastian kelembaban udara sebesar 1,3\%. Analisis ketidakpastian resolusi dihitung menggunakan analisis distribusi rectangular dan ketidakpastian tegangan ditentukan dari ketidakpastian sertifikat kalibrasi clamp meter standar sebesar $0,10 \mathrm{~V}$.

Ketidakpastian baku gabungan diestimasi dengan penjumlahan akar kuadrat dari seluruh komponen ketidakpastian pengukuran. Koefisien sensitivitas $C_{i}$ berfungsi untuk mengkonversikan semua komponen ketidakpastian ke dalam satuan ukur yang sama dengan besaran ukur, memberikan skala fungsi pembobot untuk setiap komponen 
ketidakpastian dan menjelaskan taksiran keluaran bervariasi dengan perubahan nilai taksiran masukan (KAN, 2002). Secara eksperimental, koefisien sensitivitas dapat ditentukan dengan memvariasikan besaran input tertentu dan menjaga besaran input lainnya tetap kostan. Pada penelitian ini, seluruh input diset seluruhnya bernilai sama dan standar sehingga $C_{i} \equiv 1$. Hasil perhitungan nilai ketidakpastian baku gabungan suhu dan kelembaban udara dari termohigrometer yang dibuat adalah $U_{C} \bar{T}=0,166^{\circ} \mathrm{C}$ dan $U_{C} \bar{H}=0,654 \%$ untuk suhu ruangan $25^{\circ} \mathrm{C}$. Sedangkan untuk suhu ruangan $28^{\circ} \mathrm{C}$ sebesar $U_{c} \bar{T}=0,166^{\circ} \mathrm{C}$ dan $U_{c} \bar{H}=0,653 \%$.

Ketidakpastian bentangan diperlukan untuk mengetahui tingkat kepercayaan hasil ukur, yang dihitung dari ketidakpastian baku gabungan dikalikan faktor cakupan $k$ ( $k=2$, ditentukan dari sertifikat kalibrasi). Faktor cakupan $k=2$ menunjukkan bahwa tingkat kepercayaan hasil ukur adalah 95,45 \% (JCGM 100, 2008). Pada penelitian ini diperoleh nilai ketidakpastian bentangan pengujian suhu dan kelembaban sebesar $U_{95} \bar{T}=0,332^{\circ} \mathrm{C}$ dan $U_{95} \bar{H}=1,308 \%$ pada suhu ruangan $25^{\circ} \mathrm{C}$. Sedangkan untuk suhu ruangan $28^{\circ} \mathrm{C}$ sebesar $U_{95} \bar{T}=0.332^{\circ} \mathrm{C}$ dan $U_{95} \bar{H}=1,306 \%$.

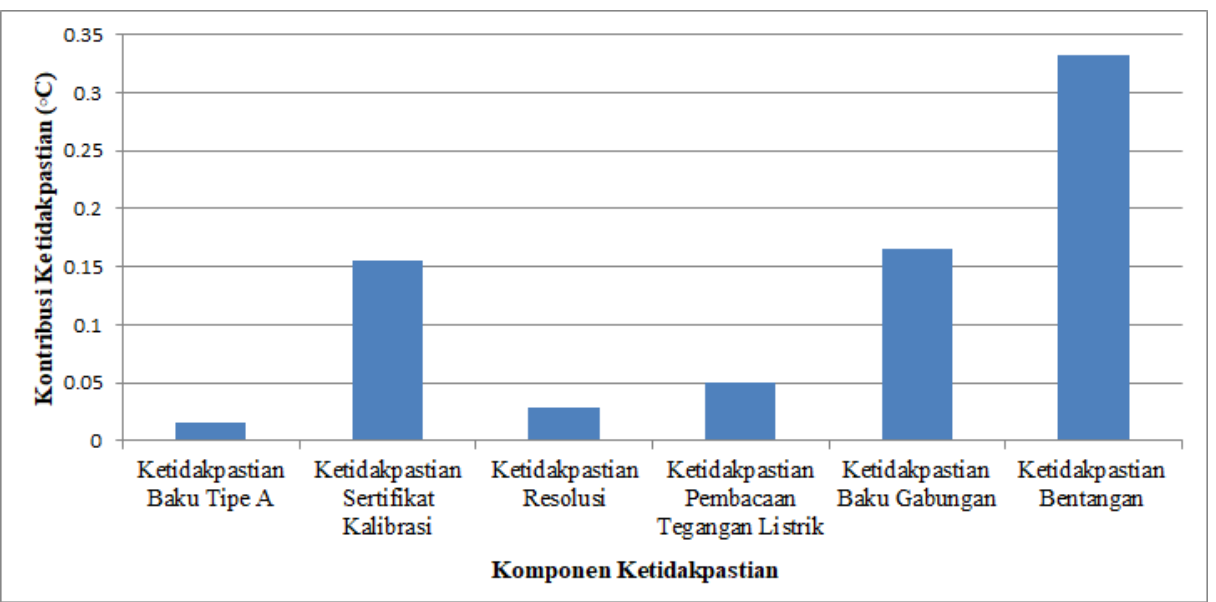

(a)

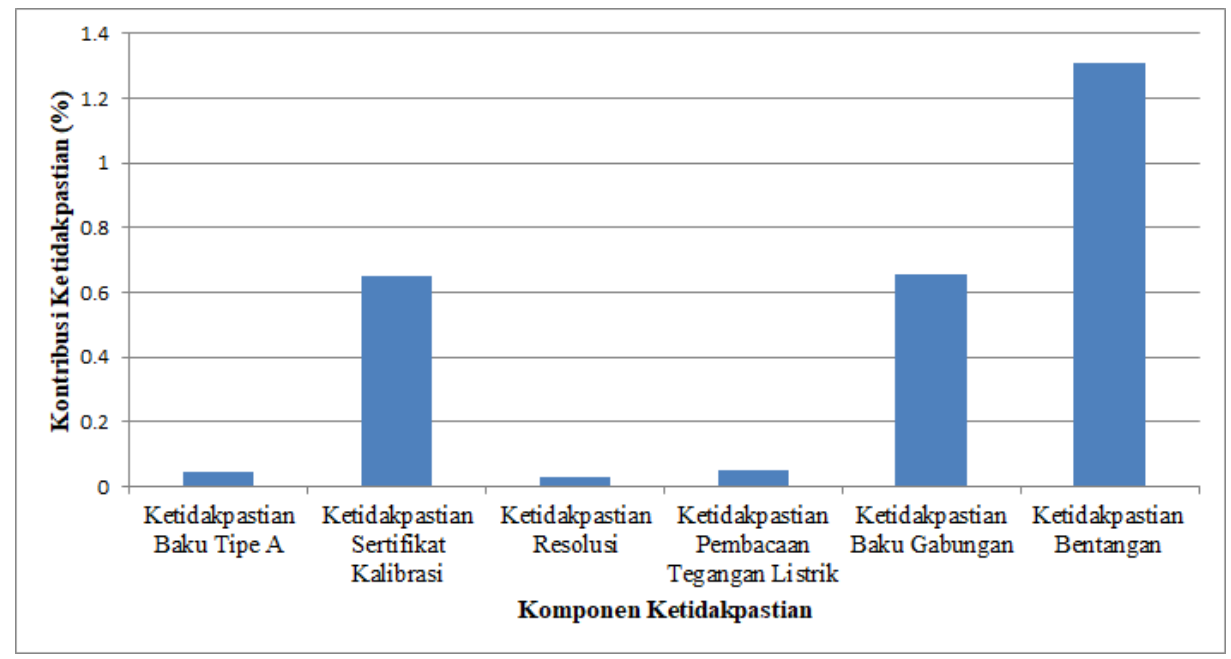

(b) 


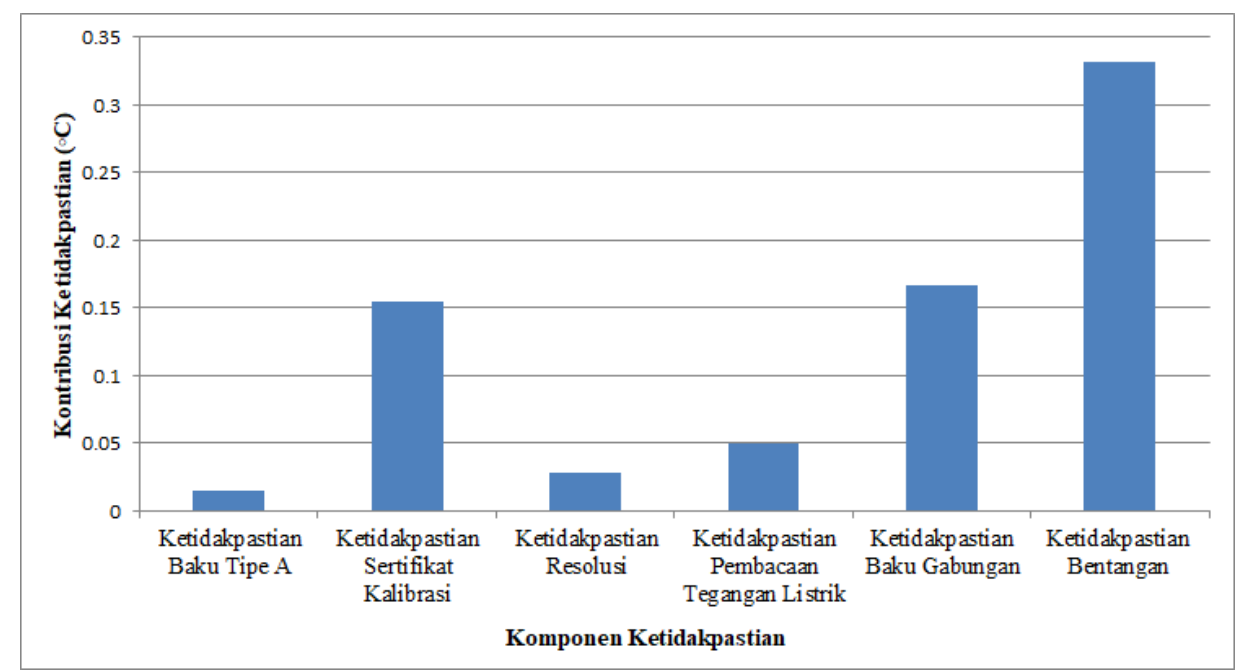

(c)

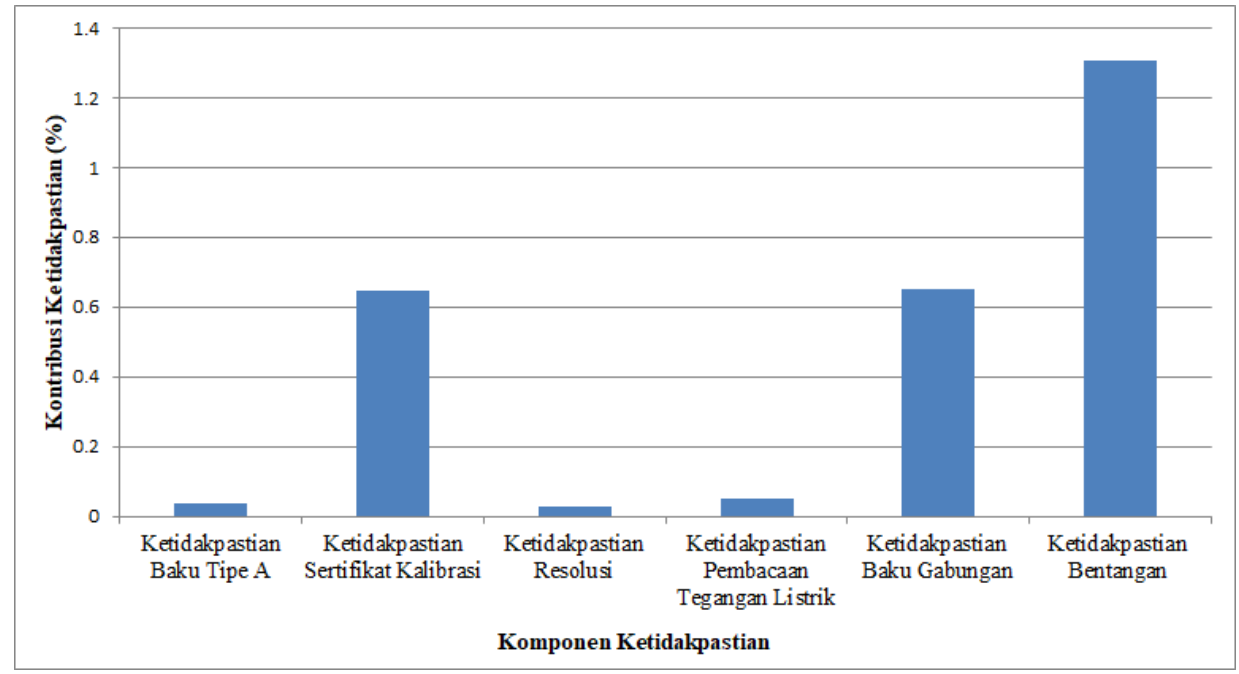

(d)

Gambar 5. Kontribusi ketidakpastian pengukuran untuk nilai suhu termohigrometer pada suhu ruangan (a) $25^{\circ} \mathrm{C}$ dan (c) $28^{\circ} \mathrm{C}$. Nilai kelembaban termohigrometer pada suhu ruangan (b) $25^{\circ} \mathrm{C}$ dan (d) $28^{\circ} \mathrm{C}$.

Pada grafik kontribusi ketidakpastian pengukuran (Gambar 5) terlihat bahwa penyumbang ketidakpastian terbesar yaitu ketidakpastian pada sertifikat kalibrasi termohigrometer standar yang digunakan sebagai pembanding. Sedangkan penyumbang kontribusi ketidakpastian yang terkecil yaitu ketidakpastian baku tipe A. Akurasi termohigrometer yang diuji pada suhu ruangan $25^{\circ} \mathrm{C}$ menunjukkan persentase nilai galat sebesar 1,34\% untuk pengukuran suhu, dan $2,72 \%$ untuk pengukuran kelembaban udara. Sedangkan ketika diuji pada suhu ruangan $28^{\circ} \mathrm{C}$ menunjukkan persentase nilai galat sebesar $1,12 \%$ untuk pengukuran suhu, dan 3,07 \% untuk pengukuran kelembaban udara. Nilai ini sudah sesuai dengan toleransi galat yang tertera pada data sheet sensor DHT22 yaitu maksimal $5 \%$ untuk kelembaban udara dan $\pm 0,2^{\circ} \mathrm{C}$ untuk suhu ruangan. 


\section{KESIMPULAN}

Hasil pengujian suhu dan kelembaban udara pada sistem termohigrometer untuk suhu ruangan $25^{\circ} \mathrm{C}$ adalah $(24,73 \pm 0,33){ }^{\circ} \mathrm{C}$ dan $(48,16 \pm 1,31) \%$. Sedangkan pada pengujian suhu dan kelembaban udara pada sistem termohigrometer untuk suhu ruangan $28^{\circ} \mathrm{C}$ adalah $(28,22 \pm 0,33)^{\circ} \mathrm{C}$ dan $(42,59 \pm 1,31) \%$. Nilai akurasi pengujian suhu dan kelembaban udara pada suhu ruangan $25^{\circ} \mathrm{C}$ menunjukkan persentase galat sebesar $1,34 \%$ dan $2,72 \%$. Untuk pengujian suhu dan kelembaban udara pada suhu ruangan $28^{\circ} \mathrm{C}$ diperoleh nilai akurasi dengan persentase galat sebesar $1,12 \%$ dan 3,07 \%. Dari hasil tersebut dapat disimpulkan bahwa hasil ukur termohigrometer yang dibuat sudah sesuai dengan standar pembacaan pada data sheet sensor DHT22.

\section{UCAPAN TERIMAKASIH}

Ucapan terimakasih dan penghargaan setinggi-tingginya kami sampaikan kepada saudara Dinar Sri Bawono dan saudari Ani Wahyu Nuur Khasanah yang telah banyak membantu dalam persiapan dan teknis pengujian sensor sehingga penelitian ini dapat terlaksana dengan baik.

\section{DAFTAR PUSTAKA}

Data sheet DHT 22. (18 Juli, 2019). http//:www.cdn-shop.adafruit.com/datasheets /DHT22.pdf

Gupta, S. V. (2012). Measurement uncertainties physical parameters and calibration of instruments (hal. 9). Berlin: Springer-Verlag.

Jumaila, S. I., \& Maulida, S. (2017). Pemantauan suhu dan kelembaban di laboratorium kalibrasi tekanan dan volume berbasis web secara real time. Jurnal Otomasi Kontrol dan Instrumentasi, 9 (1), 9-19.

Joint Committee for Guides in Metrology (JCGM) 100:2008. (2008). Evaluation of measurement data-guide to the expression of uncertainty in measurement (hal. 1116). Sèvres Cedex: Author.

Komite Akreditasi Nasional (KAN). (2002). Pedoman evaluasi dan pelaporan ketidakpastian pengukuran (hal. 1-32). Jakarta: Pengarang.

Mihai, B. (2016). How to use the DHT22 sensor for measuring temperature and humidity with the Arduino board. ACTA Universitatis Cibiniensis, 68 (1), 22-25.

Saptadi, A. H., Kurnianto, D., \& Suryani. (2015). Rancang bangun termohygrometer digital menggunakan sistem mikropengendali Arduino dan Sensor DHT22. Prosiding Seminar Nasional Sains dan Teknologi ke-6, Fakultas Teknik, Universitas Wahid Hasyim (hal. 83-88). Semarang, Indonesia.

Tistomo, A. S. (2014). Studi metode kalibrasi termohigrometer elektrik. Jurnal Standardisasi, 16 (3), 119-204. 